\title{
(Non-)agreement of passive participles in South-Eastern Lithuanian
}

\author{
Kirill Kozhanov \& Peter Arkadiev \\ Vilnius University
}

The phenomenon of non-agreement of passive participles (mostly $t$-participles) is discussed on the basis of the TriMCo corpus of South-Eastern Lithuanian dialects. A quantitative analysis of the examples shows that non-agreeing $t$-participles appear significantly more often in East Aukštaitian than in South Aukštaitian. It is also shown that plural subjects and position of the participle before the subject increase the probability of use of the non-agreeing form. At the same time we show that (non-)agreement of passive constructions in South-Eastern Lithuanian dialects does not correlate with the semantic type of passive. We also argue that the Lithuanian dialectal constructions with non-agreeing passive participles are most probably not related to the similar constructions in East Slavic (either areally, or diachronically). The non-agreeing passive constructions are also not areally related to non-agreeing active participle constructions, but probably illustrate the same tendency for the lack of agreement with plural subjects.

Keywords: Lithuanian, participles, agreement, dialectology, passive

\section{Introduction ${ }^{1}$}

In this paper we offer a corpus-based quantitative analysis of the passive constructions in South-Eastern Lithuanian dialects with the focus on the agreement and non-agreement of passive participles with their nominative subjects. It is a well-established fact that in some Aukštaitian dialects non-agreeing forms of participles can appear with full-fledged nomina-

\footnotetext{
${ }^{1}$ We are grateful to Axel Holvoet, Nicole Nau and Birute Spraunienè as well as two anonymous reviewers for their useful comments on the first version of this paper and to Wayles Browne for his careful proofreading. All faults and shortcomings remain ours. This research has received funding from the European Social Fund (project No. 09.3·3-LMT-K-712-01-0071) under grant agreement with the Research Council of Lithuania (LMTLT).
} 
tive subjects in canonical passives (see e.g. Ambrazas 1990, 200-201), as in example (1).

(1) $s k l \not ̉ \times p-a s \quad$ pa-dari-t-a

cellar-NOM.SG PVB-do-PST.PP-NA

'the cellar is built' (South Aukštaitian, Leskauskaitè 2006, 63)

Although non-agreement of passive participles is also attested in Standard Lithuanian (see Nau et al., this volume, section 2.3), there they seem to be restricted to specific contexts such as enumeration of items or comparison of alternatives. These constraints do not apply to the dialectal constructions under discussion. Our goal is to investigate the extent of the use of non-agreeing passive participles in South-Eastern Lithuanian dialects and to try to pinpoint the factors potentially favouring or disfavouring their non-agreement as well as the areal connections of this phenomenon.

The data for this study come from the TriMCo Corpus of South-Eastern Lithuanian dialects, which is a part of the larger project covering different Baltic and Slavic dialects (https://www.trimco.uni-mainz.de/trimcodialectal-corpus/) led by Björn Wiemer at the University of Mainz. The corpus contains transcribed narratives of over 140 ooo tokens (including the interviewers' lines), or 21 hours and 25 min in running time, recorded in four districts in Lithuania (Švenčionių, Druskininkų sav., Varènos, Ignalinos) and in Belarus (Ramaškancy, Pel'asa). The corpus is divided into two equal parts covering two major Aukštaitian groups-East Aukštaitian vilniškiai (Lith. rytų aukštaičiai vilniškiai) and South Aukštaitian (Lith. pietu aukštaičiai). The recordings were transcribed using the ELAN software (https://tla.mpi.nl/tools/tla-tools/elan/), and then morphologically annotated (on the basis of the 'Salos glossing rules', see Nau \& Arkadiev 2015) using the Fieldworks Language Explorer tool (FLEx; http://fieldworks.sil.org/ flex/). All Lithuanian dialectal transcriptions in the TriMCo corpus use additional IPA diacritics: : for long vowels, , for half-long vowels, ${ }^{j}$ for palatalization. The vertical line | marks a pause in a sentence. As these dialects do not distinguish between different types of accent on monophthongs, we decided to mark stress by a neutral symbol ' (in case of diphthongs, the same symbol is used on one of the elements of the diphthong). See Wiemer et al. (2019) for more information about the corpus.

The remainder of the article is structured as follows: in section 2 we briefly introduce the system of participles and their main uses in Standard 
Lithuanian, in section 3 we present an overview of the passive participles attested in the TriMCo corpus, and in section 4 deal specifically with the distribution of agreeing and non-agreeing participles in canonical passive constructions. Section 5 offers a discussion of possible areal connections of the phenomenon of passive participle non-agreement.

\section{Participles and passive in Standard Lithuanian}

Standard Lithuanian has a complex system of participles, both active and passive, derived in all available tenses, see Table 1 with the example of the verb daryti 'do'. Note that we do not consider the non-inflecting participles, traditionally called 'gerunds', as well as the agreeing converb of simultaneity in -dam- (the 'half-participle') and the debitive participle in -tin-; for more details on the Lithuanian participles and non-finite forms in general, see Ambrazas, ed. (2006, 326-372), Klimas (1987), Wiemer (2001), Arkadiev, Holvoet \& Wiemer (2015, 28-31) and Arkadiev (2020).

Table 1. The system of participles in Lithuanian

\begin{tabular}{l|ll} 
& Active $\mathbf{(} \mathbf{M}, \mathbf{F})$ & Passive $\mathbf{( M ,} \mathbf{F})$ \\
\hline Present & darąs, daranti & daromas, daroma \\
Future & darysiąs, darysianti & darysimas, darysima \\
Past & daręs, dariusi & darytas, daryta \\
Past Habitual & darydavęs, darydavusi & -
\end{tabular}

Participles agree for number, gender and case with their head when used in the attributive position, $\mathrm{cf}$. (2), and with the nominative subject when used in the predicative position (Ambrazas 2006, 483-485), cf. (3)

(2) Darbinink-ai visk-a ǐs-met-e worker-NOM.PL everything-ACC PVB-throw-PST.3 i at-važiav-usi-a šiukšli-u $\quad$ mašin-q̨... in PVB-drive-PST.PA-ACC.SG.F garbage-GEN.PL car-ACC.SG 'The workers threw everything into the garbage truck that arrived.' (DLKT)

(3) $T-a$ that-ACC.sG $r y t-a$ morning-ACC.SG istatybviet-e in construction.site-ACC.SG 


\begin{tabular}{lll} 
buv-o & \multicolumn{1}{c}{ at-važiav-us-i } & automašin-a \\
be-PST.3 & PVB-drive-PST.PA-NOM.SG.F & car-NOM.SG \\
su & kalk-émis. & \\
with & lime-INS.PL &
\end{tabular}

'A truck with lime arrived at the construction site that morning.' (DLKT)

Under certain circumstances predicatively used participles in Standard Lithuanian can lack agreement, see Arkadiev 2017 for an overview, and Nau et al. (this volume, section 2.3) specifically on passive participles. These are the cases of default agreement (or 'neuter gender', according to Ambrazas, ed., 2006, 346, 371-372), and non-inflecting participles or gerunds (Ambrazas, ed., 2006, 339-340). The gerunds are used in dependent clauses whose subject (usually overt and marked by the dative or accusative case) is distinct from the nominative subject of the main clause (for more details see Arkadiev 2013, 2020 and literature therein); these forms won't be discussed here.

Generally, default agreement forms (glossed NA for 'non-agreement') appear when the subject is either not in the nominative, as in (4), or is altogether lacking, as in (5), or when a nominative subject is deficient in terms of gender (e.g., such words as kas 'what', viskas 'everything', tai 'that'), as in example (6), see also Sawicki (2004). For active participles the default form is identical to NOM.PL.M (e.g. dara from 'do'), and for passive participles a special form (segmentally identical to NOM.SG.F, but sometimes differing from it by accent) is used, cf. ùz̆drausta (NA) v. uždraustà (NOM.SG.F.) from 'forbid'.

(4) Dèl

$$
t-o
$$

j-iems

$b \bar{u}-t y$

reikejj-e

for that-GEN.SG.M

3-DAT.PL.M be-SBJV.3

need-PST.PA.NA

dalyvau-ti

ši-u

met-u

pasauli-o

participate-INF

this-GEN.PL

year-GEN.PL

world-GEN.SG

čempionat-e.

championship-LOC.sG

'For this reason they would need to participate in this year's world championship.' (DLKT)

(5) $T-q$

klaid-a

$b \bar{u}-t u$

reikejj-e

that-ACC.SG

mistake-ACC.SG

be-sBJv.3

need-PST.PA.NA

kaip nors ati-taisy-ti.

how INDF PVB-correct-INF

'It would be necessary to fix that mistake somehow.' (DLKT) 
(6) $K-q$

$\begin{array}{llll}\text { what-ACC } & \text { 3-NOM.PL.M } & \text { be.obliged-PRS.3 } & \text { and } \\ k \text {-as } & y \text { ra } & \text { uždraus-t-a? } & \\ \text { what-NOM } & \text { be.PRS.3 forbid-PST.PP-NA } & \\ \text { 'What is required from them, and what is prohibited?' (DLKT) }\end{array}$

The canonical sentential passive constructions in Lithuanian employ the present or past passive participles of transitive verbs together with the auxiliary būti 'be', which can be omitted in the present tense and sometimes also in the past tense. For a comprehensive description of the passive in Standard Lithuanian see Geniušienè (2006; 2016); Nau et al. (this volume) provide a comparative perspective on Latvian and Lithuanian passives and related constructions.

Constructions with the present passive participles ( $m$-participles) are used imperfectively and denote ongoing or habitual situations, as in (7a), while past passive participles ( $t$-participles) are used either perfectively, expressing completed situations, as in (7b), or statively, as in example (8) (thus there is no overt distinction between actional and statal passive in Lithuanian; on the relations between passive and resultative in Lithuanian see Geniušienė \& Nedjalkov 1988). In the canonical passive, the accusative patient object of the original active construction is promoted to the nominative subject, with which the auxiliary agrees in person and number and the participle in gender and number (and nominative case). The original agent can be expressed by a genitive noun phrase, as in (9).

(7) (a) $\check{S}$ i-uo

met-u tok-s istatym-as

this-INS.SG.M

time-INS.SG

such-NOM.SG.M

law-NOM.SG

yra

rengi-a-m-as,

be.PRS.3

prepare-PRS-PP-NOM.SG.M

(b) ir

$\begin{array}{lcrl}\text { ir } & \text { tik-i-m-a-si, } & k \text { kd } & \text { artimiausi- } u \\ \text { and } & \text { hope-PRS-PP-NA-RFL } & \text { that } & \text { nearest-INS.SG.M } \\ \text { met- } u & j \text {-is } & \boldsymbol{b u} \text {-s } & \text { pri-im-t-as. } \\ \text { time-INS.SG } & \text { 3-NOM.SG.M } & \text { be-FUT.3 } & \text { PVB-take-PST.PP-NOM.SG.M }\end{array}$

'Now such a law is being prepared, and hopefully it will be passed in the nearest future.' (DLKT)

(8) Ne-si-girdejj-o NEG-RFL-hear-PST.3

nes siaut $-\dot{e}$

because

$\begin{array}{lll}\begin{array}{l}\text { net } \\ \text { even }\end{array} \quad \text { chužnyči-os } & \text { varp-u, } \\ \text { epidemij-a } & \text { bell-GEN.PL } \\ & \text { ir }\end{array}$

epidemic-NOM.SG and 
bažnyči-os buv-o uždary-t-os.

church-NOM.PL be-PST.3 close-PST.PP-NOM.PL.F

'Even church bells could not be heard, because an epidemic was raging, and churches were closed.' (DLKT)

(9) Po

$\begin{array}{lllll}\text { Po } & \text { trejet-o } & \text { dien- } u & v e l & b u v-a u \\ \text { after } & \text { three-GEN.SG } & \text { day-GEN.PL } & \text { again } & \text { be-PST.1SG }\end{array}$

j-o pa-kvies-t-as.

3-GEN.SG.M PVB-call-PST.PP-NOM.SG.M

'After three days I was again invited by him.' (DLKT)

In addition to the canonical passive, there is a variety of non-canonical constructions with passive participles, e.g. impersonal, built both from intransitive and transitive verbs and implying a human agent, see examples (10-11), and evidential, employing the same morphology as impersonal but differing from it in terms of both lexical input and morphosyntax, see (12). On non-canonical passives in Lithuanian see e.g. Timberlake (1982), Wiemer (2004, 2006), Lavine (2010, 2016), Spraunienè et al. (2015) and Nau et al. (2020). In all these constructions the participle features the nonagreeing default form and the subject, if present at all, shows genitive case marking, see again Sawicki (2004).

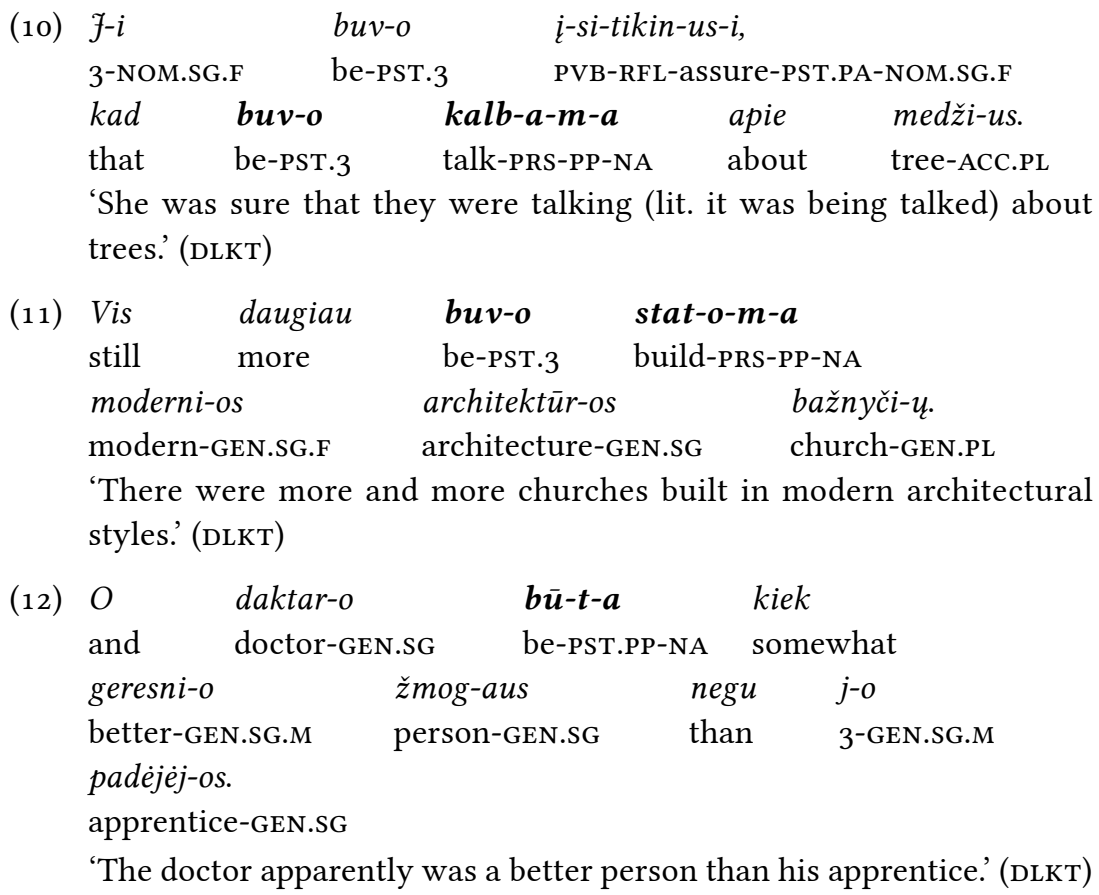


Against this background, we shall now describe the morphosyntax of the passive constructions in the South-Eastern Lithuanian dialects, which is in certain respects different from the standard language. The focus is put on the agreement in passive participles.

\section{Passive participles in the TriMCo corpus}

South-Eastern Lithuanian dialects demonstrate a great disbalance between the present and past passive participles. The $m$-participles are extremely rare: in the whole corpus we found only 15 uses (9 lemmas), and no examples from the Lithuanian dialects in Belarus. Most examples of the $m$-participles are adjectival and do not show a passive meaning, cf. (13), where the participle valgomas means 'edible', but not 'being eaten'. This is in line with the observation by Ambrazas $(1990,191)$ that the periphrastic passive constructions with the present passive participles widespread in the standard language are limited to the Žemaitian and West Aukštaitian dialects, while in the East Aukštaitian dialects such participles are mainly used adjectivally.
(13) kaz lè:k-ai
tai ce
válgo'm-i
suillus-NOM.PL
that here
edible-NOM.PL.M
'Suillus mushrooms are edible' (east)

On the other hand, the $t$-participles are well represented in the corpus. We found 545 uses of the $t$-participles representing 283 lemmas. It is worth noting that a similar disbalance between present and past participles is observed among active participles, where the present forms are also extremely rare, cf. Table 2 .

Table 2. Total number of participles in the TriMCo corpus

\begin{tabular}{l|l|l} 
& active & passive \\
\hline present & $13(2 \%)$ & $15(3 \%)$ \\
past & $781(98 \%)$ & $545(97 \%)$ \\
Total & $794(100 \%)$ & $560(100 \%)$
\end{tabular}

In the following discussion, we will focus on the $t$-participles in the TriMCo corpus. 
The $t$-participles seem to be somewhat more frequent in East Aukštaitian than in South Aukštaitian, and within the latter particularly infrequent in Belarus. But still their productivity (estimated by the share of hapax legomena, see Baayen 1993) is more or less equal across the regions, see Table 3 .

Table 3. t-participles in the TriMCo corpus

\begin{tabular}{l|lll} 
& $\begin{array}{l}\text { east } \\
(65,593 \text { tokens })\end{array}$ & $\begin{array}{l}\text { south } \\
(42,319 \text { tokens })\end{array}$ & $\begin{array}{l}\text { Belarus } \\
(34,989 \text { tokens })\end{array}$ \\
\hline tokens & 316 & 144 & 85 \\
item per 10,000 & 48,18 & 34,03 & 24,29 \\
lemmas & 196 & 89 & 60 \\
hapaxes & $150(47.5 \%)$ & $68(47,2 \%)$ & $49(57.6 \%)$
\end{tabular}

Out of 283 lemmas, 5 appear in the corpus at least 10 times, see Table 4 . There are 198 hapaxes (36\%), which once again prove a high productivity of the $t$-participles in the Lithuanian dialects under discussion.

Table 4. The most frequent $\mathrm{t}$-participles in the TriMCo corpus

\begin{tabular}{l|l} 
Lemma & Frequency \\
\hline padarytas 'done' & 43 \\
pastatytas 'built' & 24 \\
būtas 'been' & 23 \\
mokytas 'taught' & 11 \\
išaustas 'woven' & 10
\end{tabular}

There are no restrictions on the morphological features of the $t$-participles. They can be negated, have a prefix or a reflexive marker, see ex. $\left(14^{-15}\right)$. It should be noted that all examples of the reflexive $t$-participles are prefixed. The distribution of these features is given in Table 5 . 
Table 5. Morphological features of the t-participles in the TriMCo corpus

\begin{tabular}{l|l|l|l} 
& Negation & Prefix & Reflexivity \\
\hline yes & $25(5 \%)$ & $433(79.5 \%)$ & $9(2 \%)$ \\
no & $520(95 \%)$ & $112(20.5 \%)$ & $536(98 \%)$
\end{tabular}
(14) $\boldsymbol{n e}$-s $\dot{\boldsymbol{e}}$ - $\boldsymbol{t}-\boldsymbol{a}$
NEG-SOW-PST.PP-NA nothing-NOM
'nothing is sown' (south)
(15) $s^{j} p^{i} n-e^{r} l-e^{r}$
nú-s-im-t-a

lock-DIM-NOM.SG

PVB-RFL-take-PST.PP-NA

'the lock is taken off' (south)

The $t$-participles are used predicatively (512 instances, or $94 \%$ of all examples), cf. (14-16), attributively (26 uses, or 5\%), cf. (17), or independently as heads of noun phrases (7 uses, or $1 \%$ ), cf. (18).
(16) vi:r-as i'š-veš-t-as bú $\cdot v-o^{*}$
husband-NOM.SG PVB-carry-PST.PP-NOM.SG.M be-PST.3
' $[\mathrm{my}]$ husband was deported' (east)
(17) vanden-ú:k-a. dúo:-dav-o ǎs-kalbè $-\boldsymbol{t}-\boldsymbol{a}$.
water-DIM-GEN.SG give-HAB-PST.3 PVB-speak-PST.PP-GEN.SG.M
'[they] used to give enchanted water' (east)
(18) tai šit-uós mokin-t-us iv
so this-ACC.PL.M educate-PST.PP-ACC.PL.M and
$i \cdot \check{s}^{j}-v e \check{z}-e^{r} \quad$ vis-ús
PVB-carry-PST.3 all-ACC.PL.M
'so [the Soviets] deported all these educated [ones]' (east)

Most predicatively used participles function as the main predicate of the clause with or without auxiliary, see examples (15-16) above, however there are a few examples when they are used as a part of a complex predicate, see example (19), or as a secondary predicate, see example (20):
(19) iš-ein- $a$
suótk-o's
lie:k-a
PVB-go-PRS.3
are-NOM.PL
remain-PRS.3
ne-sé:-t-o's
NEG-SOW-PST.PP-NOM.PL.F
'it turns out the land remains not sown [with crops]' (east) 

(20) $k i \cdot t-u \cdot$
rá'd-a*
$n u-s ̌ a ̀ u-t-u$
other-ACC.sG find-PST.3
PVB-shoot-PST.PP-ACC.SG
'[they found] the other one shot' (east)

In most cases $t$-participles describe an action or a resultative state, however there are examples when these participles are lexicalized. Such instances are especially common when participles are used attributively or independently, cf. $k^{j}$ riśc čitas tè:vas 'godfather', lit. 'baptized father' (Belarus), or mokintas 'educated' lit. 'taught' (see ex. (18) above), išvežtieji 'deportees' lit. 'carried out' (probably from the standard language).

When used predicatively, $t$-participles can take part in different types of passive constructions (487 instances, or $95 \%$ of all predicatively used examples), cf. (21) for an actional and (22) for a statal (=resultative) passive, as well as in evidential constructions (25 instances, or $5 \%$ ), cf. (23):

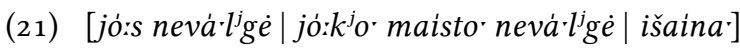

rús-u bü-s uš-nuodi-ta

Russian-GEN.PL be-FUT.3 PVB-poison-PST.PP-NA

'[they didn't eat, they didn't eat any food, assuming they] will be poisoned by Russians' (south)

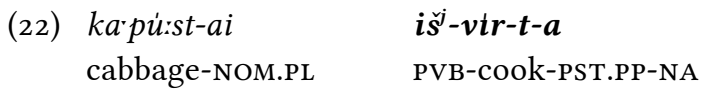

'the cabbage is cooked' (east)

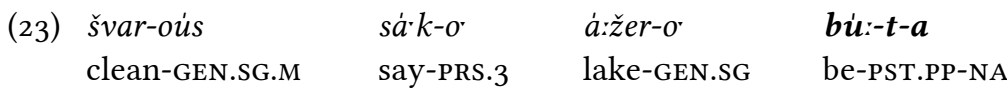

'[they] say there used to be a clean lake' (south)

Most passive constructions have an object promoted to subject and marked by the nominative case without an overtly expressed agent, cf. (24).

(24) ló:v-os pa-kló:-t-oz graž-ei bed-NOM.PL PVB-cover-PST.PP-NOM.PL.F beautiful-ADV 'the beds are covered beautifully' (south)

There is only one example in the corpus where the object is not promoted to the subject position and keeps the accusative marking, cf. (25):
(25) vi's-u liétuv-u máno
all-AcC.sG Lithuania-AcC.sg my
'I travelled across all Lithuania' (east)
$a p-v a \check{z}$ ú $-t-a$
PVB-drive-PST.PP-NA 
There are a few examples of impersonal passive without a nominative subject, see (26) and (27):

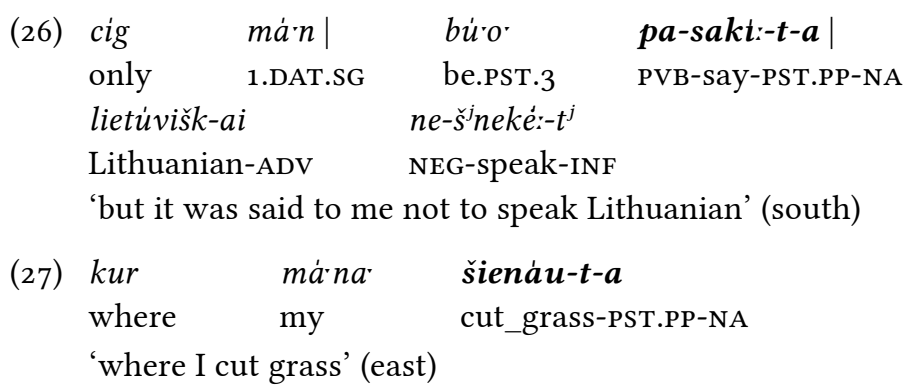

As can be seen from the examples (21) and (27) above, the agent can be optionally expressed by the genitive or a possessive pronoun. Out of 487 passive constructions, there are only 22 examples (or $4.5 \%$ of all cases ${ }^{2}$ ) with an expressed agent, see also the following example:

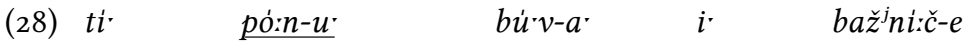 there lord-GEN.PL be-PST.3 and church-NOM.SG
stati:-t-a
build-PST.PP-NOM.SG.F
'the church was also built by the lords' (east)

There is one example where the agent is expressed by a prepositional phrase with the preposition nuo 'from', and this is probably not a coincidence that the context of this example is religious ${ }^{3}$ :
(29) vi's-o's
kalb-o's
a'n-o's
$i \check{s}$-ein- $a$
all-NOM.PL.F
language-NOM.PL
3-PL.NOM.F
PVB-go-PRS.3
nuó
$\underline{\text { nuo }}$
die:v-or
su-t $\boldsymbol{t}^{j}$ èr-t-a
from from
God-GEN.SG
PVB-create-PST.PP-NA
'all languages, it turns out, are created by God (lit. from God)' (east)

The evidential construction differs from the passive in that it is almost exclusively based on intransitive verbs and the erstwhile nominative subject takes the genitive marking, as in (30):

\footnotetext{
2 According to Geniušienè $(2016,146)$, passives with the expressed agent constitute about $7 \%$ of passive constructions in written Lithuanian.

${ }^{3}$ Cf. similar observations on the rare instances of agent phrases with the preposition no in Latvian passives in Nau et al. (2020).
} 


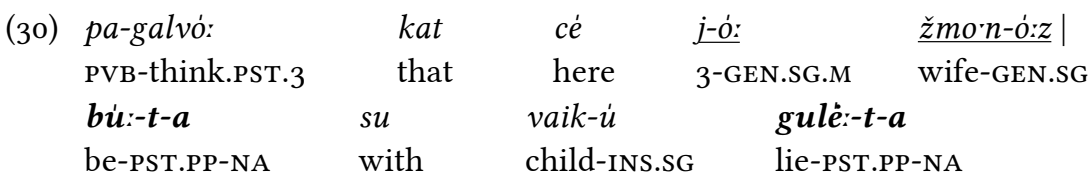
'he thought that his wife with the kid had been there, had lain [there]'

Most examples of the evidential are with the participle $b \bar{u} t a$ of the verb 'be'. There is also one example with a regular passive embedded into an evidential construction:

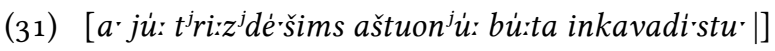

\begin{tabular}{|c|c|c|c|}
\hline $\begin{array}{l}\text { tai } \\
\text { so }\end{array}$ & $\begin{array}{l}\boldsymbol{b} \boldsymbol{u}:-\boldsymbol{t}-\boldsymbol{a} \\
\text { be-PST.PP-NA }\end{array}$ & $\begin{array}{l}\text { api-sup-t-a } \\
\text { PVB-surround-PST.PP-NA }\end{array}$ & $\begin{array}{l}i \cdot \\
\text { and }\end{array}$ \\
\hline klúo:n-as & $i$ & tvárt-as $\quad i$ & nam-ai \\
\hline barn-NOM.SG & and & shed-NOM.SG & house-NOM.PL \\
\hline
\end{tabular}

Note that the subject in the second part of (31) is marked by the nominative.

All attributively used participles are derived from transitive verbs, whereas predicatively used $t$-participles are derived from both transitive and intransitive verbs. All $t$-participles derived from intransitive verbs appear in the evidential function.

\section{4. (Non-)Agreement in passive participles}

The default (non-agreeing, or in more traditional terminology 'neuter') form of the $t$-participles appears in the corpus under the following conditions. First, it is required when the subject lacks the categories of gender and number, as in (32):

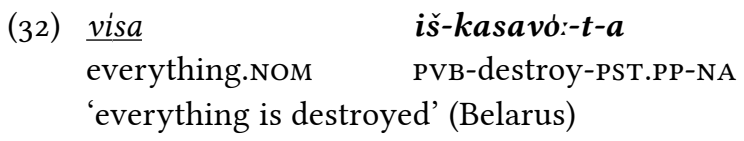

Second, when the subject is marked by the quantificational (partitive) genitive:
(33) $s^{j} a l^{j}-u k-a z$
grǎ̌-ús |
$g \dot{e} l^{j}-\dot{u}:$
table-DIM-NOM.SG
beautiful-NOM.SG.M
flower-GEN.PL 


\section{pa-staci:-t-a}

PVB-put-PST.PP-NA

'the table is beautiful, [there are] a lot of flowers put on it' (south)

Third, in the impersonal constructions, i.e. with no obvious nominative subject:

\begin{tabular}{|c|c|c|c|}
\hline cig & $m a ́ n n$ & bu'o' & pa-saki:-t-a| \\
\hline only & 1SG.DAT & be.PST.3 & PVB-Say-PST.PP-NA \\
\hline \multicolumn{2}{|c|}{ lietúvišk-ai } & $n e-\check{s}^{j} n e k \dot{e}^{\prime}-t^{j}$ & \\
\hline Lithu & $n-A D V$ & NEG-speak-INF & \\
\hline
\end{tabular}

Fourth, in the evidential constructions, where the subject is marked by the genitive, see examples (23) and (30) above. All these examples have parallels in the standard language.

Different from the standard language are the examples in which there is a subject in the nominative case, and the participle does not show any agreement with it, as in example (35). ${ }^{4}$
(35) $\underline{d u} \cdot r-\hat{\imath} s$
adari:-t-a
pójezd-o'
door-NOM.PL
open-PST.PP-NA
train-GEN.SG
'train's doors are open' (Belarus)

In order to assess the distribution of participial (non-)agreement in South-Eastern Lithuanian dialects, we excluded all examples where we would not expect agreement, i.e. constructions listed above. As a result, we had a dataset of 331 examples. Within this dataset there was another problem we had to deal with, i.e. the frequent syncretism between default forms and NOM.SG.F forms, cf. (36) where the participle aždari:ta looks identical for both forms. Such examples were marked as 'indeterminate' for agreement and, consequently, excluded from the counts.
(36) tadu
$b u^{\prime} v-a \cdot$
then
be-PST.3
jou
gi
already PTC
$a \check{z}$-dari:-t $\boldsymbol{a}$
PVB-do-PST.PP-NA/NOM.SG.F
$b a \check{z}^{j} n i: \check{c}-e$
$\operatorname{church}(\mathrm{F})$-NOM.SG
'at the time the church was already closed' (east)

\footnotetext{
${ }^{4}$ As has been already mentioned in section 2, examples of non-agreement in the presence of a full-fledged nominative subject are indeed attested in Standard Lithuanian as well, however, there such constructions appear to be much more constrained.
} 
We checked the following predictors that can potentially trigger the lack of agreement on the participle:

i) Dialectal group (East (Eastern Aukštaitian of the Vilnius region, Lith. rytų aukštaičiai vilniškiai) vs. South (South Aukštaitian in Lithuania and Belarus, Lith. pietų aukštaičiai)).

ii) Number of the subject (SG vs. PL).

iii) Gender of the subject ( $M$ vs. F).

iv) Semantic type of the passive (static vs. dynamic).

v) Auxiliary (yes, no).

vi) Position with respect to the subject (before vs. after).

The statistical analysis of the data shows that the lack of agreement in the $t$-participles is more common in the East Lithuanian dialects (the dependency between geographical distribution and the lack of agreement proves to be statistically significant), cf. Table 6. The odds of non-agreement in past passive participles are 5 times higher in East Aukštaitian dialects than in the South Aukštaitian dialects.

Table 6. (Non-)agreement of past passive participles across regions $\chi^{2}(1)=31.877 ; p<0.0001$ (Pearson's $\chi^{2}$-test), Cramér's $V=0.357$

\begin{tabular}{l|lllcc} 
& +Agr & \multicolumn{3}{c}{-Agr } & Totals \\
\hline East & 71 & $45 \%$ & 86 & $55 \%$ & $157(100 \%)$ \\
South & 85 & $81 \%$ & 20 & $19 \%$ & $105(100 \%)$
\end{tabular}

As the difference between the two dialectal groups is so large, we decided to check all other factors for the whole bulk of examples and for each dialectal group separately. Let us first look at the grammatical features of the subject and its possible effect on the agreement in the participle. The dependency between number of the subject and the lack of agreement proves to be significant: the odds of non-agreement are 4 times higher with plural subjects than with the singular ones, cf. Table 7. The factor of the number of the subject is also significant in both dialectal groups when considered separately, cf. Tables $7 \mathrm{a}-\mathrm{b}$. 
Table 7. (Non-)agreement of past passive participles and number of the subject

$\chi^{2}(1)=28.032 ; p<0.0001$ (Pearson's $\chi^{2}$-test), Cramér's $V=0.336$

\begin{tabular}{l|lllcc} 
& + Agr & \multicolumn{3}{c}{- Agr } & Totals \\
\hline SG & 116 & $73 \%$ & 43 & $27 \%$ & $159(100 \%)$ \\
PL & 40 & $39 \%$ & 62 & $61 \%$ & $102(100 \%)$
\end{tabular}

Table 7a. (Non-)agreement of past passive participles and number of the subject in East Aukštaitian

$\chi^{2}(1)=10.742 ; p=0.001$ (Pearson's $\chi^{2}$-test), Cramér's $V=0.275$

\begin{tabular}{l|lllcl} 
& + Agr & \multicolumn{3}{c}{ Totals } \\
\hline SG & 48 & $59 \%$ & 34 & $41 \%$ & $82(100 \%)$ \\
PL & 23 & $31 \%$ & 51 & $69 \%$ & $74(100 \%)$
\end{tabular}

Table $7 \boldsymbol{b}$. (Non-)agreement of past passive participles and number of the subject in South Aukštaitian

$\chi^{2}(1)=8.4312 ; p=0.0037$ (Pearson's $\chi^{2}$-test), Cramér's $V=0.311$

\begin{tabular}{l|lllcc} 
& + Agr & \multicolumn{3}{c}{- Agr } & Totals \\
\hline SG & 68 & $88 \%$ & 9 & $12 \%$ & $77(100 \%)$ \\
PL & 17 & $61 \%$ & 11 & $39 \%$ & $28(100 \%)$
\end{tabular}

However, if we look at the relationship between agreement and the gender of the subject, there is no statistically significant dependency either for the whole corpus or for either of the two dialectal areas, see Table 8.

Table 8. (Non-)agreement of past passive participles and gender of the subject $\chi^{2}(1)=0.70352 ; p=0.4016$ (Pearson's $\chi^{2}$-test), Cramér's $V=0.062$

\begin{tabular}{l|lllcc} 
& + Agr & \multicolumn{3}{c}{- Agr } & Totals \\
\hline masculine & 123 & $58 \%$ & 88 & $42 \%$ & $211(100 \%)$ \\
feminine & 33 & $66 \%$ & 17 & $34 \%$ & $50(100 \%)$
\end{tabular}


Table 8a. (Non-)agreement of past passive participles and gender of the subject in East Aukštaitian

$\chi^{2}(1)=0.11915 ; p=0.73$ (Pearson's $\chi^{2}$-test), Cramér's $V=0.044$

\begin{tabular}{l|lllcc} 
& + Agr & \multicolumn{3}{c}{- Agr } & Totals \\
\hline masculine & 56 & $56 \%$ & 70 & $46 \%$ & $126(100 \%)$ \\
feminine & 15 & $50 \%$ & 15 & $50 \%$ & $30(100 \%)$
\end{tabular}

Table 8b. (Non-)agreement of past passive participles and gender of the subject in South Aukštaitian

$p=0.3509$ (Fisher's exact test), Cramér's $V=0.112$

\begin{tabular}{l|lllcc} 
& + Agr & \multicolumn{5}{c}{-Agr } & Totals \\
\hline masculine & 67 & $79 \%$ & 18 & $21 \%$ & $85(100 \%)$ \\
feminine & 18 & $90 \%$ & 2 & $10 \%$ & $20(100 \%)$
\end{tabular}

Let us now look at the properties of the passive construction as a whole. First, we look at the word order, namely the position of the passive participle with respect to the subject. This factor proves to play a somewhat significant role in the distribution of non-agreeing forms, as they generally appear more often before the subject. ${ }^{5}$ The odds of the non-agreeing participle appearing before the subject is 3.3 times higher than appearing after it, see Table 9. However, if we look at this factor in the two dialectal groups separately, it proves to be significant only in East Aukštaitian, cf. Tables 9a-b.

Table 9. (Non-)agreement of past passive participles and the position of the subject

$\chi^{2}(1)=11.802 ; p<0.0006$ (Pearson's $\chi^{2}$-test), Cramér's $V=0.223$

\begin{tabular}{l|lllll} 
& +Agr & \multicolumn{3}{c}{- Agr } & \multicolumn{2}{c}{ Totals } \\
\hline participle before S & 16 & $36 \%$ & 29 & $64 \%$ & $45(100 \%)$ \\
participle after S & 140 & $65 \%$ & 77 & $35 \%$ & $217(100 \%)$
\end{tabular}

${ }^{5}$ The same seems to apply to the use of the non-agreeing passive participles in Standard Lithuanian discussed in Nau et al. (2020, section 2.3). 
Table 9a. (Non-)agreement of past passive participles and the position of the subject in East Aukštaitian

$\chi^{2}(1)=10.068 ; p=0.0015$ (Pearson's $\chi^{2}$-test), Cramér's $V=0.269$

\begin{tabular}{l|lllll} 
& +Agr & \multicolumn{3}{c}{- Agr } & \multicolumn{2}{c}{ Totals } \\
\hline participle before S & 6 & $19 \%$ & 26 & $81 \%$ & $32(100 \%)$ \\
participle after S & 65 & $52 \%$ & 60 & $48 \%$ & $125(100 \%)$
\end{tabular}

Table $9 b$. (Non-)agreement of past passive participles and the position of the subject in South Aukštaitian

$p=0.7$ (Fisher's exact test), Cramér's $V=0.039$

\begin{tabular}{l|lllll} 
& +Agr & & - Agr & \multicolumn{2}{c}{ Totals } \\
\hline participle before S & 10 & $77 \%$ & 3 & $23 \%$ & $13(100 \%)$ \\
participle after S & 75 & $82 \%$ & 17 & $18 \%$ & $92(100 \%)$
\end{tabular}

It has also been claimed that agreeing passive participles occur significantly less frequently without an overt auxiliary than in the presence of the auxiliary in all Baltic languages (Ambrazas 1990, 194). This suggests that the absence of the auxiliary would correlate with the lack of agreement in the participle. However, the data from the TriMCo corpus does not support this hypothesis. The presence or absence of the overt auxiliary does not seem to play any statistically significant role in the agreement on the participle, see Tables 10 and 10a-b.

Table 10. (Non-)agreement of past passive participles and presence of the auxiliary $\chi^{2}(1)=0.2628 ; p=0.6$ (Pearson's $\chi^{2}$-test), Cramér's $V=0.041$

\begin{tabular}{l|lllll} 
& + Agr & \multicolumn{3}{c}{- Agr } & \multicolumn{2}{c}{ Totals } \\
\hline overt auxiliary & 47 & $62 \%$ & 29 & $38 \%$ & $76(100 \%)$ \\
no auxiliary & 104 & $57 \%$ & 77 & $43 \%$ & $181(100 \%)$
\end{tabular}


Table 1oa. (Non-)agreement of past passive participles and presence of the auxiliary in East Aukštaitian

$\chi^{2}(1)=1.2729 ; p=0.26$ (Pearson's $\chi^{2}$-test), Cramér's $V=0.105$

\begin{tabular}{l|lllll} 
& + Agr & \multicolumn{3}{c}{- Agr } & Totals \\
\hline overt auxiliary & 24 & $52 \%$ & 22 & $48 \%$ & $46(100 \%)$ \\
no auxiliary & 44 & $41 \%$ & 64 & $59 \%$ & $108(100 \%)$
\end{tabular}

Table 1ob. (Non-)agreement of past passive participles and presence of the auxiliary in South Aukštaitian $\chi^{2}(1)=0.13685 ; p=0.71$ (Pearson's $\chi^{2}$-test), Cramér's $V=0.063$

\begin{tabular}{l|lllll} 
& + Agr & \multicolumn{3}{c}{- Agr } & Totals \\
\hline overt auxiliary & 23 & $77 \%$ & 7 & $23 \%$ & $30(100 \%)$ \\
no auxiliary & 60 & $82 \%$ & 13 & $18 \%$ & $73(100 \%)$
\end{tabular}

Finally, we have tested whether there is a correlation between the semantic type of the passive (actional vs. static-resultative) and the (non-) agreement of the participle. It has been suggested that the main function of the non-agreeing constructions is to describe the state of the subject (Ambrazas 1990, 200). Therefore, one could speculate that non-agreeing forms would appear more often in the static-resultative passive constructions. Bearing in mind that semantic interpretation of passive constructions is not always straightforward, the coding process was organized in the following way: both authors coded the examples independently, then the results were compared and the examples with conflicting judgments were discussed separately. In the end we managed to agree on the interpretation of the majority of examples, however in four cases we could not come up with any solution, so these cases were excluded from the statistics. The results are given in Tables 11 and $11 \mathrm{a}-\mathrm{b}$ and show that there is no statistically significant correlation between semantics and presence of agreement either in general or in either of the dialectal areas taken separately. 
Table 11. (Non-)agreement of past passive participles and the semantic type of passive

$\chi^{2}(1)=0.17657 ; p<0.6743$ (Pearson's $\chi^{2}$-test), Cramér's $V=0.035$

\begin{tabular}{l|lcccc} 
& + Agr & \multicolumn{3}{c}{- Agr } & Totals \\
\hline static & 100 & $61 \%$ & 65 & $39 \%$ & 165 \\
dynamic & 49 & $57 \%$ & 37 & $43 \%$ & 86
\end{tabular}

Table 11a. (Non-)agreement of past passive participles and the semantic type of passive in East Aukštaitian $\chi^{2}(1)=0.6736 ; p=0.41$ (Pearson's $\chi^{2}$-test), Cramér's $V=0.081$

\begin{tabular}{l|lllcc} 
& +Agr & \multicolumn{3}{c}{- Agr } & Totals \\
\hline static & 47 & $47 \%$ & 54 & $53 \%$ & $101(100 \%)$ \\
dynamic & 19 & $38 \%$ & 31 & $62 \%$ & $50(100 \%)$
\end{tabular}

Table 11b. (Non-)agreement of past passive participles and the semantic type of passive in South Aukštaitian $\chi^{2}(1)=1.8725 \mathrm{e}-30 ; p=1$ (Pearson's $\chi^{2}$-test), Cramér's $V=0.007$

\begin{tabular}{l|llccc} 
& + Agr & \multicolumn{3}{c}{- Agr } & \multicolumn{2}{c}{ Totals } \\
\hline static & 53 & $83 \%$ & 11 & $17 \%$ & $64(100 \%)$ \\
dynamic & 30 & $83 \%$ & 6 & $17 \%$ & $36(100 \%)$
\end{tabular}

Thus, only the factors of region, number of the subject and its linear position with respect to the passive participle turned out to be significant - though by no means deterministic - predictors of the choice of agreeing vs. non-agreeing $t$-participle. The non-agreeing default form of the $t$-participle is favored by plural subjects, postposed subjects and especially frequently occurs in the East Aukštaitian dialects. 


\section{Discussion and conclusions}

The statistical analysis of the South-Eastern Lithuanian dialects shows that non-agreeing predicative past passive participles appear more often in East Aukštaitian than in South Aukštaitian.

Ambrazas (1990, 201-203) argues for the archaic nature of non-agreeing passive constructions, comparing them, on the one hand, with the similar constructions in East Slavic and, on the other hand, with the non-agreeing adjectives describing the state of the subject such as shown in (37).

$$
\begin{aligned}
& \text { (37) al-us gard-u } \\
& \text { beer(M)-NOM.SG tasty-NA } \\
& \text { 'the beer is tasty' }
\end{aligned}
$$

The comparison with East Slavic does not seem to be straightforward. At first sight, non-agreeing past passive participles in the Lithuanian dialects indeed find their parallel in the Northwest Russian dialects, especially often in the Novgorod dialects, see Kuz'mina \& Nemčenko (1971, 28,34 ), cf. example (38).

(38) Northwest Russian

$$
\begin{array}{lll}
m u \check{z}=t o & u=n e j & u b i-\boldsymbol{t}-\boldsymbol{o} \\
\text { husband(M)[NOM.SG]=PTC } & \text { at=she.GEN } & \text { kill-PST.PP-N } \\
\text { 'Her husband has been killed.' (Pskov region, Kuz'mina \& Nemčenko } \\
\text { 1971, 35) }
\end{array}
$$

However, it is unclear whether the Lithuanian dialectal construction with the non-agreeing $t$-participle is a direct areal counterpart of the similar Northwest Russian construction (see e.g. its discussion in Seržant 2012 and references therein), since the two areas seem to be disconnected. Such constructions do not reach the territory of the Belarusian dialects, see the map in Požarickaja $(2014,129)$. In some Northern Belarusian dialects, similar constructions with the subject, probably marked by the accusative, are rarely attested, cf. (39):

(39) Northern Belarusian

$h r y b-y$ pa-zbirá- $n-a$

mushroom-NOM/ACC.PL PVB-collect-PST.PP-NA

'the mushrooms are picked' (Vicebsk region, Avanesaŭ, ed., 1964, 301)

Still more importantly, as was convincingly argued by Trubinskij $(1984,120-122)$, the East Slavic dialectal construction is of fairly recent 
development (2oth century), hence the areal connection with Aukštaitian is highly improbable.

However, the non-agreeing passive participles have been compared to the non-agreeing past active participles in Lithuanian dialects, e.g. (40), see Ambrazas (1990, 202-205), as well as to the special non-inflecting active participles (gerunds) in East Slavic dialects, e.g. (41), see Kuz'mina \& Nemčenko (1971, 116-223), Trubinskij (1984, 121-122), both used in resultative-perfect constructions (see Wiemer \& Giger 2005 for a general comparative overview and Danylenko 2020 for a new look at their origins).

(40) South Aukštaitian; TriMCo corpus

$\begin{array}{llll}\text { died-e } & o^{\cdot} & \text { sen-ei } & \text { tan-é } \\ \text { uncle-voc } & \text { and } & \text { old-ADv } & \text { Tanya-NOM.sG }\end{array}$

bu่'o atvažáa:v-ì?

be.PST.3 arrive-PST.PA.NA

'uncle, has Tanya come a long time ago?'

(41) Russian dialects (Tver region)

on-a belj-e stira-vši

3-NOM.SG.F clothes-ACC.SG wash-PST.PA.NA

'she has washed clothes' (Kuz'mina \& Nemčenko 1971, 132)

However, as was shown by Kozhanov (2018), the distribution of nonagreeing past active participles in South-Eastern Lithuanian dialects is different from that of non-agreeing past passive participles: non-agreeing past active participles appear more commonly in South Aukštaitian (especially in the dialects spoken in Belarus), cf. Table 12 also based on the TriMCo corpus.

Table 12. (Non-)agreement of past active participles across regions $\chi^{2}(2)=59.447 ; p<0.0001$ (Pearson's $\chi^{2}$-test), Cramér's $V=0.368$

\begin{tabular}{l|ccccc} 
& + Agr & \multicolumn{3}{c}{-Agr } & \multicolumn{2}{c}{ Totals } \\
\hline East & 189 & $94 \%$ & 12 & $6 \%$ & $201(100 \%)$ \\
South & 135 & $89 \%$ & 17 & $11 \%$ & $152(100 \%)$ \\
Belarus & 52 & $60 \%$ & 35 & $40 \%$ & $87(100 \%)$
\end{tabular}

In other words, even though the phenomenon of non-agreement is found in both active and passive past participles, its distribution is different. This 
might hint at a different origin of such non-agreement. Non-agreeing past active participle forms are primarily attested in the Lithuanian dialects of Belarus and might be a result of Slavic influence on the model of the - všy type participles, whereas the non-agreeing past passive participles look like a distinct phenomenon, possibly of an archaic origin. However, at the grammatical level both phenomena are related to the more general tendency towards lack of agreement with plural subjects (the factor of number is relevant for past active participles as well, see Kozhanov 2018).

Another important outcome of our study is the demonstration of the fact that non-agreeing passive constructions in South-Eastern Lithuanian dialects do not correlate with the semantic type of passive. Even though it was suggested for East Slavic (Trubinskij 1988, 405-406) and hinted at for Lithuanian (Ambrazas 1990, 200) that non-agreeing passive participles tend to have stative (=resultative) semantics while agreeing constructions seem to be more common in actional passives, our data did not corroborate this hypothesis for South-Eastern Lithuanian dialects.

\section{Abbreviations}

1 - 1st person, 2 - 2nd person, 3 - 3rd person, ACC - accusative, ADV - adverb, DAT - dative, DIM - diminutive, F - feminine, FUT - future, GEN - genitive, НAB - habitual, INDF - indefinite, INF - infinitive, INS - instrumental, LOC - locative, $\mathrm{M}$ - masculine, $\mathrm{N}$ - neuter, NA - non-agreeing form, NEG negation, NOM - nominative, PA - active participle, PL - plural, PP - passive participle, PRS - present, PST - past, PTC - particle, PVB - preverb, RFL reflexive, SBJv - subjunctive, SG - singular, voc - vocative

\section{SOURCES}

DLKT $=$ The Corpus of Modern Lithuanian, tekstynas.vdu.lt

TriMCo $=$ The corpus of Baltic and Slavic languages created within the project Triangulation Approach for Modelling Convergence with a High Zoom-In Factor, https://www.trimco.uni-mainz.de/trimco-dialectal-corpus/, not fully available online 


\section{REFERENCES}

Ambrazas, Vytautas. 1990. Sravnitelnyj sintaksis pričastij baltijskix jazykov [Comparative syntax of participles in the Baltic languages]. Vilnius: Mokslas.

Ambrazas, Vytautas, ed. 2006. Lithuanian Grammar. Vilnius: Baltos lankos.

Arkadiev, Peter. 2017. Two types of non-agreeing participles in Lithuanian: implications for the theories of agreement and case. Workshop Participles: Form, Use and Meaning, 5oth Annual Meeting of the Societas Linguistica Europaea, Zürich, 10-13 September 2017.

Arkadiev, Peter. 2020. (Non)finiteness, constructions, and participles in Lithuanian. Linguistics 58.2, 379-424.

Arkadiev, Peter, Axel Holvoet \& Björn Wiemer. 2015. Introduction: Baltic linguistics - state of the art. In: Peter Arkadiev, Axel Holvoet \& Björn Wiemer, eds., Contemporary Approaches to Baltic Linguistics. BerlinBoston: De Gruyter Mouton, 1-109.

Avanesaŭ, R. I., ed. 1964. Narysy pa belaruskaj dyjalektalohii [Studies in Belarusian Dialectology]. Minsk: Navuka i texnika.

BAAYEN, R. HARALD. 1993. On frequency, transparency, and productivity. In: Geert E. Booij \& Jaap van Marle, eds., Yearbook of Morphology 1992. Dordrecht: Kluwer, 181-208.

DANYLENKO, ANDRII. 2020. On the grammaticalization of the - $(v) s ̌$ - resultative in North Slavic. In: Bridget Drinka, ed., Historical Linguistics 2017. Selected Papers from the 23rd International Conference on Historical Linguistics, San Antonio, Texas, 31 July-4 August 2017. Amsterdam-Philadelphia: John Benjamins, 293-316.

Geniušiené, Emma. 2006. Passives in Lithuanian (in comparison with Russian). In: Werner Abraham \& Larisa Leisiö, eds., Passivization and Typology. Form and Function. Amsterdam-Philadelphia: John Benjamins, 29-61.

Geniušiené, Emma. 2016. Passive Constructions in Lithuanian. Selected Works by Emma Geniušienè, edited by Anna Kibort \& Nijolè Maskaliūnienè, transl. by Artūras Ratkus. Amsterdam-Philadelphia: John Benjamins.

Geniušienė, Emma \& Vladimir P. Nedjalkov. 1988. Resultative, passive, and perfect in Lithuanian. In: Vladimir P. Nedjalkov, ed., Typology of Resultative Constructions. Amsterdam-Philadelphia: John Benjamins, 369-386.

Klimas, Antanas. 1987. The Lithuanian participles: Their system and functions. Lituanus 33, 38-73. 
KozHAnOv, KIRILl. 2018. (Non)Agreement of past participles in Aukštaitian Lithuanian dialects. Presentation at the International conference Grammar of Non-Standard Varieties in the East of the Circum-Baltic Area, University of Tartu, February 1-3, 2018.

Kuz'mina, Irina B. \& Elena V. Nemčenko. 1971. Sintaksis pričastnyx form $v$ russkix govorax [Syntax of participial forms in the Russian dialects]. Moscow: Nauka.

LAVINE, James E. 2010. Mood and a transitivity restriction in Lithuanian: The case of the inferential evidential. Baltic Linguistics 1. 115-142.

LAVINE, JAMES E. 2016. Variable argument realization in Lithuanian impersonals. In: Axel Holvoet \& Nicole Nau, eds., Argument Realization in Baltic. Amsterdam-Philadelphia: John Benjamins, 107-135.

LesKaUsKaité, Asta. 2006. Kučiūnu krašto šnektos tekstai [Dialectal texts from the Kučiūnai region]. Vilnius: Lietuvių kalbos instituto leidykla.

Nau, Nicole \& Peter Arkadiev. 2015. Towards a standard of glossing Baltic languages: The Salos Glossing Rules. Baltic Linguistics 6, 195-241.

Nau, Nicole, Biruté Spraunienė \& Vaiva Žeimantiené. 2020. The Passive Family in Baltic. Baltic Linguistics 11: Studies in the Voice Domain in Baltic and Its Neighbours (thematic issue), 27-128.

PožArickAjA, SofiJA. K. 2014. O lingvogeografičeskix parametrax funkcionirovanija pričastnyx form $\mathrm{v}$ russkix govorax [On the areal distribution of participial forms in Russian dialects]. In: Ilja A. Seržant \& Björn Wiemer, eds., Contemporary Approaches to Dialectology: The Area of North, North-West Russian and Belarusian Dialects. Bergen: University of Bergen, 109-129.

SAW ICKI, LEA. 2004. Neuter passive participle in Modern Lithuanian. In: Philip Baldi \& Pietro U. Dini, eds., Studies in Baltic and Indo-European Linguistics. In Honor of William R. Schmalstieg. Amsterdam-Philadelphia: John Benjamins, 157-164.

SERŽAnt, IljA. 2012. The so-called possessive perfect in North Russian and the Circum-Baltic Area. A diachronic and areal account. Lingua 122, $356-385$.

Sprauniené, Biruté, Auksé Razanovaitė \& Erika Jasionyté. 2015. Solving the puzzle of the Lithuanian passive. In: Axel Holvoet \& Nicole Nau, eds., Voice and Argument Structure in Baltic. Amsterdam-Philadelphia: John Benjamins, 323-365.

Timberlake, Alan. 1982. The impersonal passive in Lithuanian. Proceedings of the 8th Annual Meeting of the Berkeley Linguistics Society, 508-524. 
Trubinskij, VAlentin I. 1984. Očerki russkogo dialektnogo sintaksisa [Studies in Russian dialectal syntax]. Leningrad: Izdatel'stvo Leningradskogo universiteta.

Trubinskij, Valentin I. 1988. Resultative, passive and perfect in Russian dialects. In: Vladimir P. Nedjalkov, ed., Typology of Resultative Constructions. Amsterdam-Philadelphia: John Benjamins, 369-386.

Wiemer, BJörn. 2001. Partizipien zwischen Syntax, Semantik und Pragmatik: Ein Überblick zu aspektuellen, diathesebezogenen und diskursrelevanten Eigenschaften im modernen Litauischen. In: Bernhard Wälchli \& Fernando Zúñiga, eds., Sprachbeschreibung und Typologie. Bern: Universität Bern, 65-81.

Wiemer, BJörn. 2004. The evolution of passives as grammatical constructions in Northern Slavic and Baltic languages. In: Walter Bisang, Nikolaus P. Himmelmann \& Björn Wiemer, eds., What Makes Grammaticalization? A Look from Its Fringes and Its Components. Berlin-New York: Walter de Gruyter, 271-331.

WiEMER, BJÖRN. 2006. Relations between actor-demoting devices in Lithuanian. In: Werner Abraham \& Larisa Leisiö, eds., Passivization and Typology: Form and Function. Amsterdam-Philadelphia: John Benjamins, 274-309.

Wiemer, Björn, Kirill KožAnov \& Aksana Èrker. 2019. Korpus slavjanskix i baltijskix govorov TriMCo: struktura, celi i primery primenenija [The TriMCo corpus of Slavic and Baltic dialects: structure, goals, and examples of application]. Balto-slavjanskie issledovanija 20, 122-143.

WiEmer, BJörn \& MARKus Giger. 2005. Resultativa in den nordslavischen und baltischen Sprachen (Bestandsaufnahme unter arealen und grammatikalisierungstheoretischen Gesichtspunkten). München, Newcastle: LINCOM.

\section{Kirill Kozhanov \\ Peter Arkadiev}

Vilnius University

Institute for the Languages and Cultures of the Baltic

Universiteto 5, LT-O1131 Vilnius

kirill.kozhanov@flf.vu.lt

peter.arkadiev@flf.vu.lt 